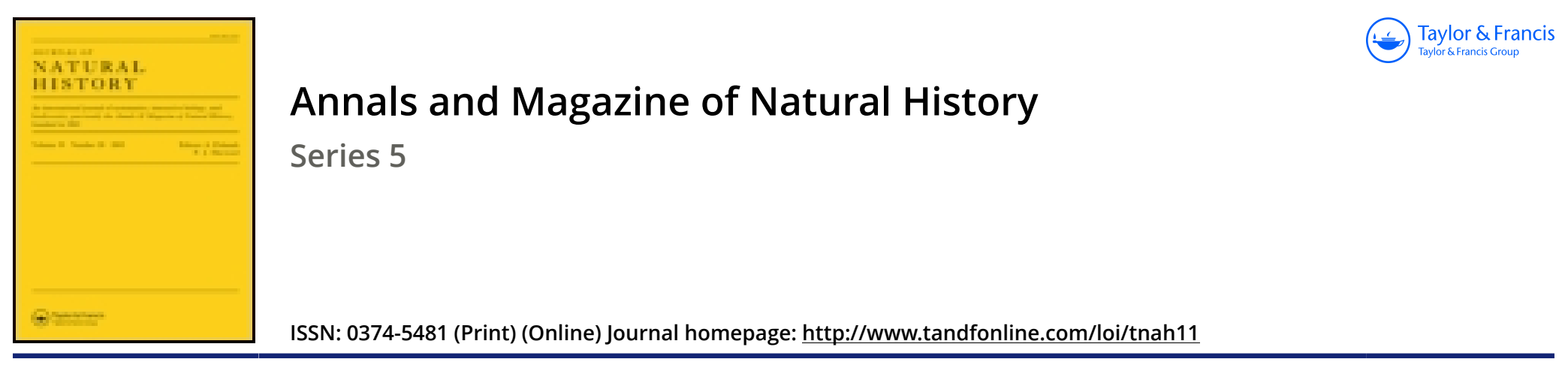

\title{
LVII.-Description of an African species of the Coleopterous genus Helota, MacLeay
}

\section{A. Sidney Olliff}

To cite this article: A. Sidney Olliff (1884) LVII.-Description of an African species of the Coleopterous genus Helota, MacLeay , Annals and Magazine of Natural History, 13:78, 479-480, DOI: $10.1080 / 00222938409459281$

To link to this article: http://dx.doi.org/10.1080/00222938409459281

冓 Published online: 07 Oct 2009.

Submit your article to this journal $\sqsubset \pi$

Џ Article views: 3

Q View related articles $\asymp$ 
This species appears to differ from any previously known in the armature of the thorax.

Amboina.

\section{SALTATORIA.}

\section{Gryllidæ.}

11. Gryllus capensis.

Acheta capensis, Fabr. Syst. Eat. p. 281 (17\%5).

St. Vincent, Cape Verdes, July 1873; Green Mountain, Ascension, April 1876.

12. Anastostoma australasioe.

Anastostoma australusie, Gray, Mag. Nat. Hist. (2) i. p. 143, fig. 16 (18:37).

Somerset, Torres Straits, Sept. 1874.

A single immature specimen.

LVII.-Description of an African Species of the Coleopterous Genus Helota, MacLeay. By A. Sidney OllifF.

THE species I am about to describe was collected by the late Dr. Welwitsch at Angola, and was recently received by Mr. Martin Jacoby in a box, containing chiefly Phytophagous Coleoptera, from Signor Paulino d'Oliveira, of Coimbra, in Portugal. I have elsewhere pointed out (Cist. Ent. iii. p. 49) that all the previously known species of the genus Helota are found in Eastern Asia, and therefore the species here described is of special interest, as showing that the genus is of far wider range than could have been anticipated. Lord Walsingham informs me that he has received from Bathurst, West Africa, a new species of Deuterocopus, Zeller (belonging to the Lepidopterous family Pterophoridæ), a genus which, up to the present time, has only been known from Java.

This appears to be a somewhat similar and equally unexpected case of geographical distribution.

\section{Helota africana, sp. n.}

Elongate, depressed, narrowed both in front and behind, pale fulvous, shining; the head, disk of the prothorax, a spot near the base, and the apical half of each elytron black. 
The head rather broad, slightly convex, strongly and not very closely punctured in the middle, the punctures much finer and closer near the sides; epistoma rounded in front, finely and closely punctured; mandibles black and very finely punctured. Antennæe reddish testaceous, the elub pitchy black and covered with fine grey pubescence. Prothorax considerably narrowed towards the apex, moderately convex; the disk black, highly polished, strongly and sparingly punctured; the sides fulvous and finely punctured; the large punctures are arranged in two longitudinal irregular patches extending throughout the whole length of the prothorax, one on each side of the middle; anterior margin bisinuate, the angles very slightly produced; sides oblique; posterior margin very strongly bisinuate, the angles acute. Scutellum transverse, black and impunctate. Elytra about half as long again as the head and prothorax together, as broad at the base as the prothorax, slightly narrowed posteriorly, moderately strongly punctate-striate, the seventh interstice somewhat raised, the others rather broad, flat, and impunctate; each elytron with an elongate spot near the base between the third and fourth strix and the apical half black, the latter with a slight tinge of greenish bronze; humeral angles notvery prominent. Underside fulvous and impunctate; head black, finely and closely punctured behind the eyes; the mentum very sparingly punctured; prosternum with an obscure black patch on each side extending from just behind the anterior margin to the middle. Legs fulvous; the coxæ, knees, tips of the tibia, and the tarsi pitchy black. Length 13 millim., greatest width 4 millim. Museum.

Angola, West Africa (Welwitsch). Type in Lisbon

This pretty species is one of the most distinct of all the described species of the genus. In form it appears to approach Helota Servillei, Hope, but differs not only in the absence of the flavous callosities so conspicuous in that species, but also in having the prothorax comparatively shorter and the elytra less produced at the apex. In coloration it is quite unlike any species with which $I$ am acquainted, but, on account of the absence of the flavous callosities and the apical half of the elytra being black tinged with green, it bears some slight resemblance to $H$. semifulva, Rits., with which species in other respects it has little in common.

Mr. C. O. Waterhouse proposes to figure H. africana and H. semifulya in an early number of his "Aid to the Identification of Insects.' 